\title{
The Non-Erythropoietic EPO Analogue Cibinetide Inhibits Osteoclastogenesis In Vitro and Increases Bone Mineral Density in Mice
}

\author{
Zamzam Awida ${ }^{1}$, Almog Bachar ${ }^{1}$, Hussam Saed ${ }^{1}$, Anton Gorodov ${ }^{1}$, Nathalie Ben-Califa ${ }^{1}$, Maria Ibrahim ${ }^{1}$, \\ Albert Kolomansky ${ }^{1,2}$, Jennifer Ana Iden ${ }^{3}$, Liad Graniewitz Visacovsky ${ }^{1}$, Tamar Liron ${ }^{3}$, Sahar Hiram-Bab ${ }^{3}$, \\ Michael Brines ${ }^{4} \mathbb{D}$, Yankel Gabet ${ }^{3, *,+}(\mathbb{D})$ and Drorit Neumann ${ }^{1, *,+} \mathbb{C}$
}

1 Department of Cell and Developmental Biology, Sackler Faculty of Medicine, Tel Aviv University, Tel Aviv 6997801, Israel; Zamzam.awida@gmail.com (Z.A.); almogb19950@gmail.com (A.B.); hussamsaed07@gmail.com (H.S.); anton.1985@hotmail.com (A.G.); alloulnat@gmail.com (N.B.-C.); Maria_rulez1@hotmail.com (M.I.); alexkolomansky228@gmail.com (A.K.); liadv@mail.tau.ac.il (L.G.V.)

2 Department of Medicine A, Tel Aviv Sourasky Medical Center, Sackler Faculty of Medicine, Tel Aviv University, Tel Aviv 6423906, Israel

3 Department of Anatomy and Anthropology, Sackler Faculty of Medicine, Tel Aviv University, Tel Aviv 6997801, Israel; jenniden@gmail.com (J.A.I.); tamarlrn@gmail.com (T.L.); saharurit@gmail.com (S.H.-B.)

4 Araim Pharmaceuticals, Tarrytown, NY 10591, USA; mbrines@araimpharma.com

* Correspondence: yankel@tau.ac.il (Y.G.); histo6@tauex.tau.ac.il (D.N.); Tel.: +972-3-640-7684 (Y.G.); +972-3-640-7256 (D.N.)

check for updates

Citation: Awida, Z.; Bachar, A.; Saed, H.; Gorodov, A.; Ben-Califa, N.; Ibrahim, M.; Kolomansky, A.; Iden, J.A.; Graniewitz Visacovsky, L.; Liron, T.; et al. The Non-Erythropoietic EPO Analogue Cibinetide Inhibits Osteoclastogenesis In Vitro and Increases Bone Mineral Density in Mice. Int. J. Mol. Sci. 2022, 23, 55. https: / / doi.org/10.3390/ ijms23010055

Academic Editor: José Manuel López

Received: 22 November 2021 Accepted: 18 December 2021 Published: 21 December 2021

Publisher's Note: MDPI stays neutral with regard to jurisdictional claims in published maps and institutional affiliations.

Copyright: (C) 2021 by the authors. Licensee MDPI, Basel, Switzerland. This article is an open access article distributed under the terms and conditions of the Creative Commons Attribution (CC BY) license (https:// creativecommons.org/licenses/by/ $4.0 /)$.
+ These authors contributed equally to this work.

Abstract: The two erythropoietin (EPO) receptor forms mediate different cellular responses to erythropoietin. While hematopoiesis is mediated via the homodimeric EPO receptor (EPOR), tissue protection is conferred via a heteromer composed of EPOR and CD131. In the skeletal system, EPO stimulates osteoclast precursors and induces bone loss. However, the underlying molecular mechanisms are still elusive. Here, we evaluated the role of the heteromeric complex in bone metabolism in vivo and in vitro by using Cibinetide (CIB), a non-erythropoietic EPO analogue that exclusively binds the heteromeric receptor. CIB is administered either alone or in combination with EPO. One month of CIB treatment significantly increased the cortical ( 5.8\%) and trabecular $(\sim 5.2 \%)$ bone mineral density in C57BL/6J WT female mice. Similarly, administration of CIB for five consecutive days to female mice that concurrently received EPO on days one and four, reduced the number of osteoclast progenitors, defined by flow cytometry as $\operatorname{Lin}^{-}$CD $11 b^{-}$Ly6 $\mathrm{C}^{\text {hi }}$ CD $115^{+}$, by $42.8 \%$ compared to treatment with EPO alone. In addition, CIB alone or in combination with EPO inhibited osteoclastogenesis in vitro. Our findings introduce CIB either as a stand-alone treatment, or in combination with EPO, as an appealing candidate for the treatment of the bone loss that accompanies EPO treatment.

Keywords: erythropoietin; cibinetide; osteoclasts; bone marrow derived macrophages (BMDM); EPOR; CD131

\section{Introduction}

Erythropoietin (EPO) is a glycoprotein hormone that is produced mainly by the kidneys and plays a crucial role in regulating erythropoiesis [1]. The secreted hormone acts by binding to the EPO receptor (EPOR) on erythroid progenitor cells in the bone marrow (BM), and stimulates their proliferation, differentiation, and survival. [2]

Recombinant human EPO ( $r H u E P O)$ is administered clinically for the treatment of anemia that is secondary to chronic kidney disease, or for certain hematological malignancies [3-6]. 
In addition to hematopoietic cells, EPOR has also been detected in many other cell types and is associated with cytoprotective effects in these non-hematopoietic tissues [7-12]. While erythropoiesis is mediated by the canonical EPOR homodimer, the tissue protective effects of EPO are thought to act through the heteromeric innate repair receptor (IRR) [13,14], which is composed of EPOR and the $\beta$-common receptor subunit $(\beta C R, C D 131)$. This subunit is also used for signaling by other type 1 cytokine receptors, such as GM-CSF, IL-3, and IL-5 [15-17].

A number of non-hematopoietic EPO analogs have now been developed that selectively activate the IRR and confer tissue protection without a measurable effect on the EPOR-EPOR homodimer and, consequently, without eliciting erythropoiesis or the potential associated adverse effects [18]. One promising candidate is Cibinetide (pHBSP; ARA 290) which is an 11-amino acid peptide that is modeled from the three-dimensional structure of helix B of the EPO molecule [19]. Cibinetide interacts with the IRR and has demonstrated efficacy in a number of animal models of angiogenic potential, autoimmune diseases, neuropathy, and organ transplantation [20-25].

Bone is a highly dynamic tissue that undergoes continuous remodeling throughout life in a process involving the concerted actions of monocyte-derived osteoclasts that resorb mineralized tissue, and mesenchymal osteoblasts that deposit new bone [26-28].

The tight regulation of the osteoblastic and osteoclastic lineages is thus crucial for the control of bone turnover [29-32].

The discovery that EPO has pleiotropic roles in non-hematopoietic tissues has prompted an investigation of the role of EPO in bone homeostasis [33,34]. This is due to the proximity of the bone and hematopoietic cells in the bone marrow milieu as well as the documented crosstalk between the hematopoietic and skeletal systems [35,36]. In that respect, we, and others, have shown that high EPO levels (both exogenously administered as well as a result of over-expression) lead to a dramatic bone loss in mouse models [37-42].

In accordance with these results, a growing body of evidence now links high EPO levels to bone loss in humans [43,44].

Monocyte differentiation into osteoclasts is driven by the receptor activator for nuclear factor kappa B (RANK)/RANK ligand (RANKL)/osteoprotegerin (OPG) system, and macrophage colony stimulating factor (M-CSF, CD115) [45]. In the bone marrow, these preosteoclast macrophages express EPOR and recent studies from our lab indicate that EPO stimulates osteoclastogenesis by acting directly on osteoclast precursors [38]. However, the underlying molecular mechanism that is responsible for EPO-induced bone loss is still unknown.

This study was designed to investigate the role of the EPO-R forms in bone metabolism. For this purpose, we used the non-erythropoietic EPO analog Cibinetide, which acts exclusively on the EPOR/CD131 complex.

Here we present data suggesting that Cibinetide treatment in murine models is associated with a bone-preserving effect when injected as a single agent. Moreover, Cibinetide counteracts the stimulatory effect of $\mathrm{EPO}$ on preosteoclasts, making it a very promising anti resorptive agent, either when given alone or in combination with EPO.

\section{Results}

2.1. Cibinetide (CIB) Inhibits Osteoclastogenesis In Vitro, in a Dose Dependent Manner, without Cytotoxic Effects

As the first step, we examined the effect of Cibinetide on the differentiation of bone marrow derived macrophages (BMDM) into osteoclasts as mediated by M-CSF and RANKL, which are both essential for osteoclast differentiation. TRAP staining was used to evaluate the area that was covered by osteoclasts, with treatment with EPO as the positive control for increased osteoclastogenesis [38]. Cibinetide suppressed osteoclastogenesis in a dosedependent manner. At low Cibinetide levels $(3 \mu \mathrm{M})$, osteoclastogenesis was similar to that which was observed in the control (M-CSF and RANKL only) cultures (Figure 1a,b). To exclude the possibility that inhibition of osteoclastogenesis by Cibinetide was due to the reduced viability of the osteoclast precursors, we examined the viability by MTT assay. The 
results confirmed that Cibinetide has no cytotoxic effects at concentrations that effectively inhibited osteoclast differentiation (Figure 1c).

a.

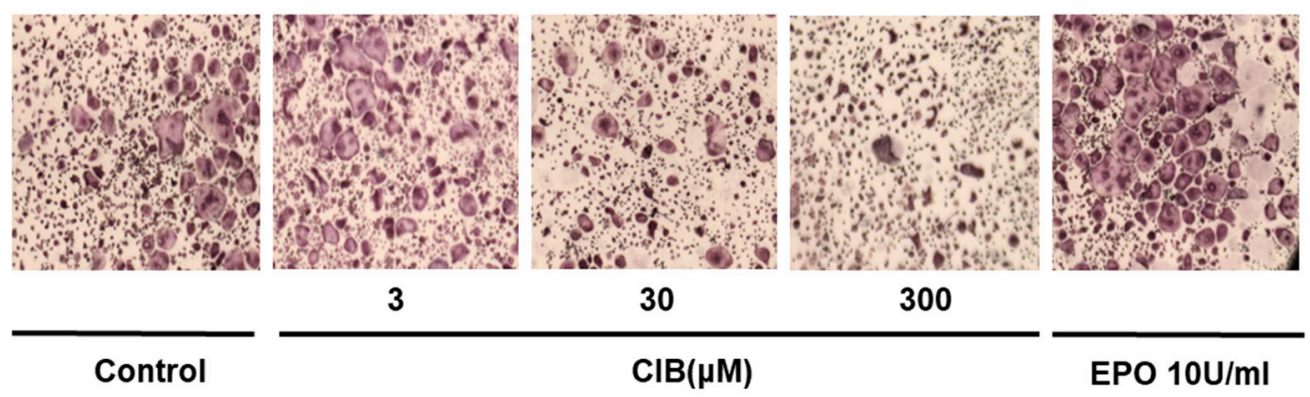

b.

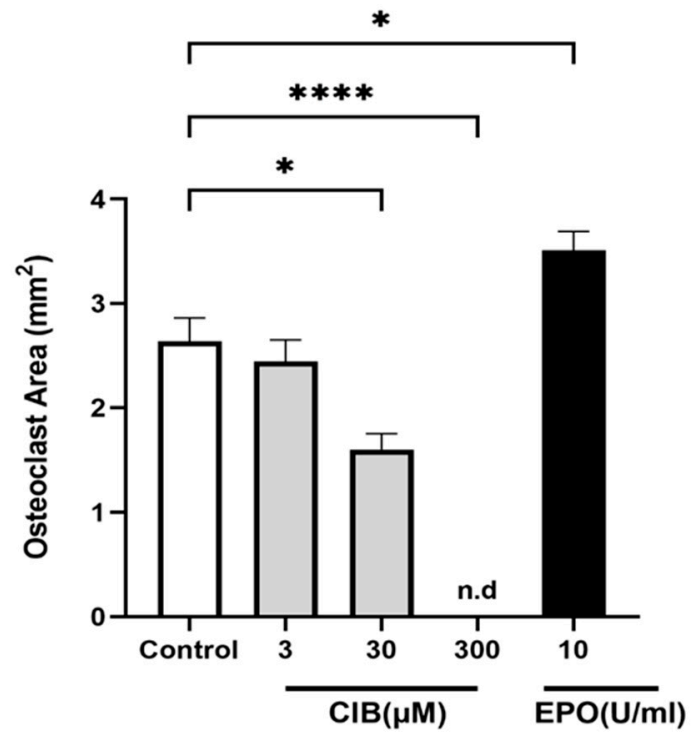

C.

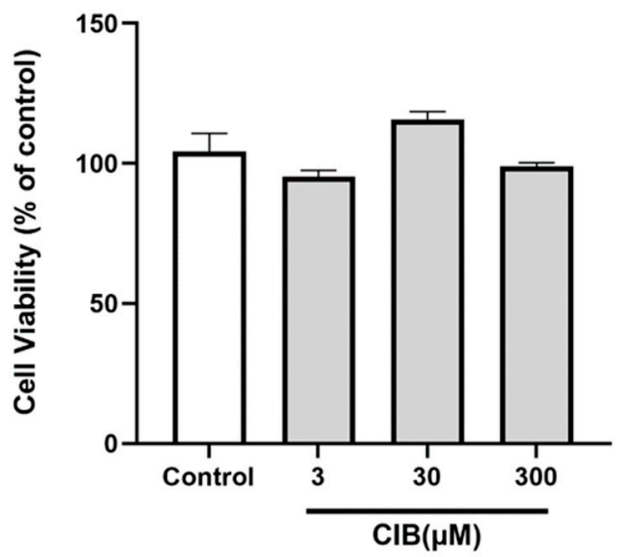

Figure 1. Cibinetide (CIB) attenuates osteoclast differentiation in vitro. BMDM were treated with Cibinetide in the presence of RANKL $(50 \mathrm{ng} / \mathrm{mL})$ and M-CSF $(20 \mathrm{ng} / \mathrm{mL})$. TRAP staining (images and $\mathrm{TRAP}^{+}$area) of osteoclasts are shown at the end of differentiation (4-5 days). (a) Representative micrographs of $\mathrm{TRAP}^{+}$osteoclasts. Original magnification at $2 \times$. (b) Quantification of the total area of $\mathrm{TRAP}^{+}$multinucleated cells. (c) BMDMs were cultured in the presence of different concentrations of Cibinetide $(3,30,300 \mu \mathrm{M})$. After $48 \mathrm{~h}$, MTT reagent was added to each well and the absorbance was measured at $560 \mathrm{~nm}$. Data from at least three independent experiments are shown as mean $\pm \mathrm{SEM}$. ${ }^{*} p<0.05,{ }^{* * * *} p<0.0001$.

\subsection{Cibinetide (CIB) Exerts Its Inhibitory Effects in the Early Stages of Osteoclastogenesis}

To determine the stage at which Cibinetide inhibits osteoclastogenesis, BMDM that were previously cultured with M-CSF only were also supplemented with RANKL at Day 0, and were treated with Cibinetide $(150 \mu \mathrm{M})$ at different times between days 0 and 4 , as shown in the schematic representation (Figure 2a). Inhibition of osteoclastogenesis was most effective when Cibinetide was introduced into the cultures at day 0 . Reduction of osteoclastogenesis by Cibinetide was far less pronounced when the compound was added at a later time point. These findings support the notion that the anti-osteoclastogenic effect of Cibinetide is manifested most strongly in the initial stages of osteoclast differentiation (Figure 2b,c). 


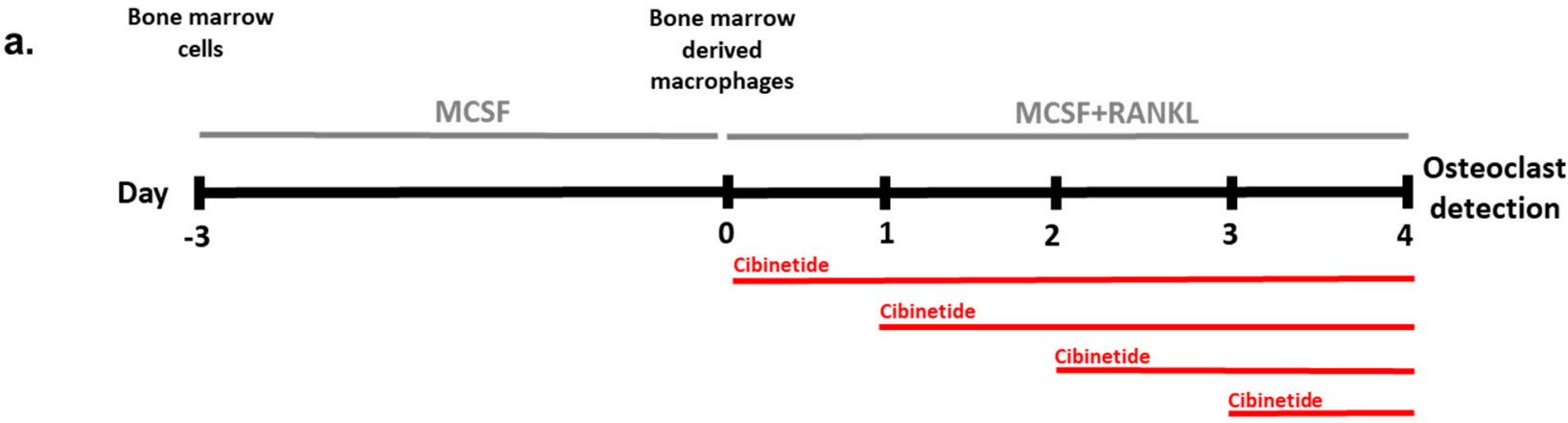

b.

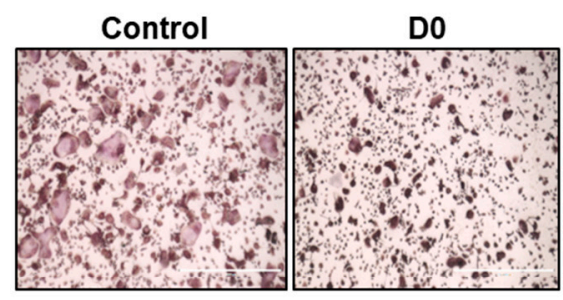

D1

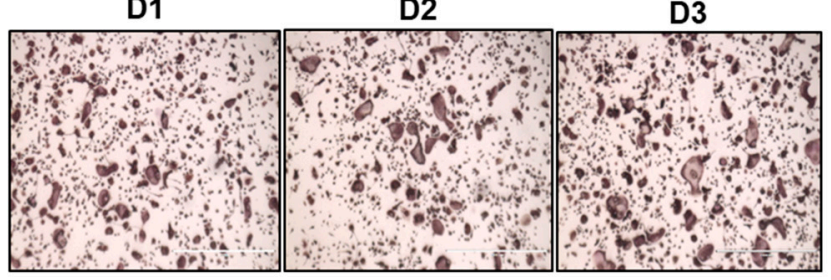

C.

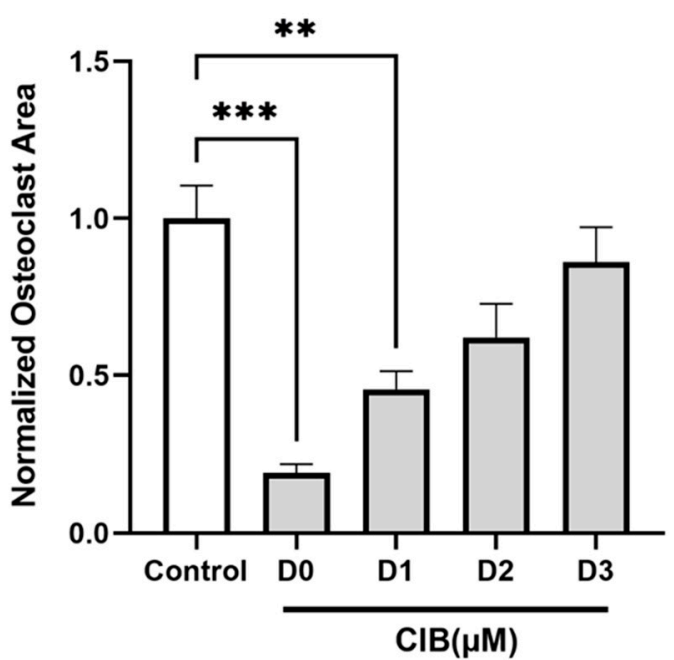

Figure 2. Cibinetide (CIB) inhibits osteoclastogenesis during the early stage of osteoclast differentiation in vitro. (a) Schematic representation of the experimental layout. (b) BMDM were treated with Cibinetide $(150 \mu \mathrm{M})$ at four different time points (indicated by red lines) in the presence of RANKL (50 ng/mL) and M-CSF (20 ng/mL). After four days, TRAP staining was performed. (c) Quantification of the total area of $\mathrm{TRAP}^{+}$multinucleated cells. Data from three independent experiments are shown as mean \pm SEM. ${ }^{* *} p<0.01,{ }^{* * *} p<0.001$.

\subsection{Cibinetide (CIB) Suppresses the Expression of Osteoclast-Related Genes}

To further examine the inhibitory effects of Cibinetide on osteoclastogenesis in response to RANKL, we examined the expression of the well-known osteoclast-related genes, Cathepsin K (CTSK), OSCAR, OC-STAMP, DC-STAMP, and NFATC1 [46]. The results (Figure 3) indicated that Cibinetide significantly inhibited the expression of all these osteoclast marker genes. These results are in accordance with the inhibitory effect of Cibinetide on osteoclastogenesis, as presented in Figures 1 and 2. Collectively, these results confirm that Cibinetide suppresses osteoclastogenesis in vitro. 


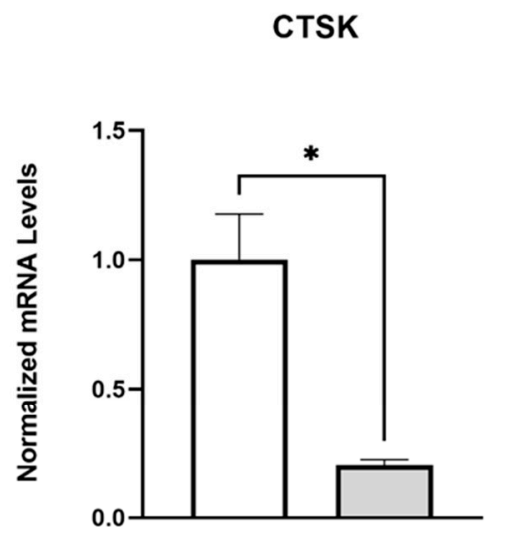

DC-STAMP

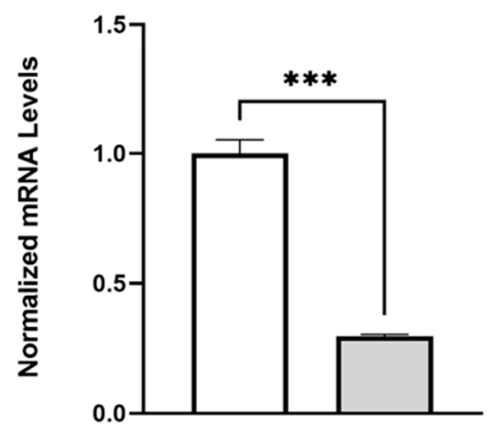

OSCAR

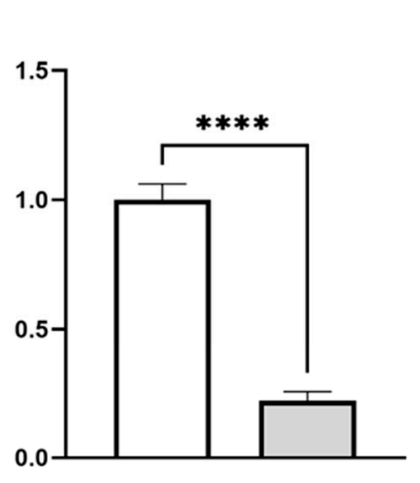

OC-STAMP

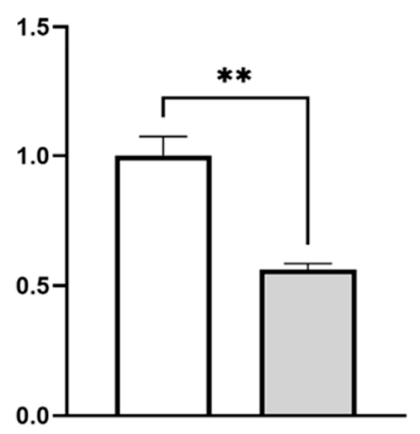

Control

CIB

Figure 3. Cibinetide (CIB) downregulates osteoclast-specific genes' expression. PCR analysis of osteoclast-specific gene expression in BMDMs stimulated with MCSF + RANKL for five days with or without Cibinetide $(150 \mu \mathrm{M})$. The expression of Cathepsin K(CTSK), OSCAR, DC-STAMP, OCSTAMP, and NFATC1 were normalized to the housekeeping gene HPRT and then to the mean of the control group. The data are expressed as mean \pm SEM of three independent experiments. ${ }^{*} p<0.05$, ${ }^{* *} p<0.01,{ }^{* * *} p<0.001$, and ${ }^{* * * *} p<0.0001$.

\subsection{Cibinetide (CIB) Overrides the Pro-Osteoclastogenic Effects of LPS and EPO}

To determine whether the anti osteoclastogenesis effect of Cibinetide can counter enhanced osteoclastogenesis, such as that which is conferred by EPO or LPS, Cibinetide was added to BMDM together with EPO or LPS as follows: BMDMs were treated with M-CSF and RANKL (50 ng/mL) together with EPO $(10 \mathrm{U} / \mathrm{mL})$ and/or Cibinetide $(150 \mu \mathrm{M})$. On the second day, LPS (10 ng/mL) was introduced to the RANKL+M-CSF or to the RANKL+M-CSF+ Cibinetide cultures. On the fourth day, multinucleated osteoclasts were stained for TRAP. The results demonstrate that Cibinetide inhibits osteoclastogenesis even in the presence of LPS or EPO (Figure $4 a, b$ ). 
a.
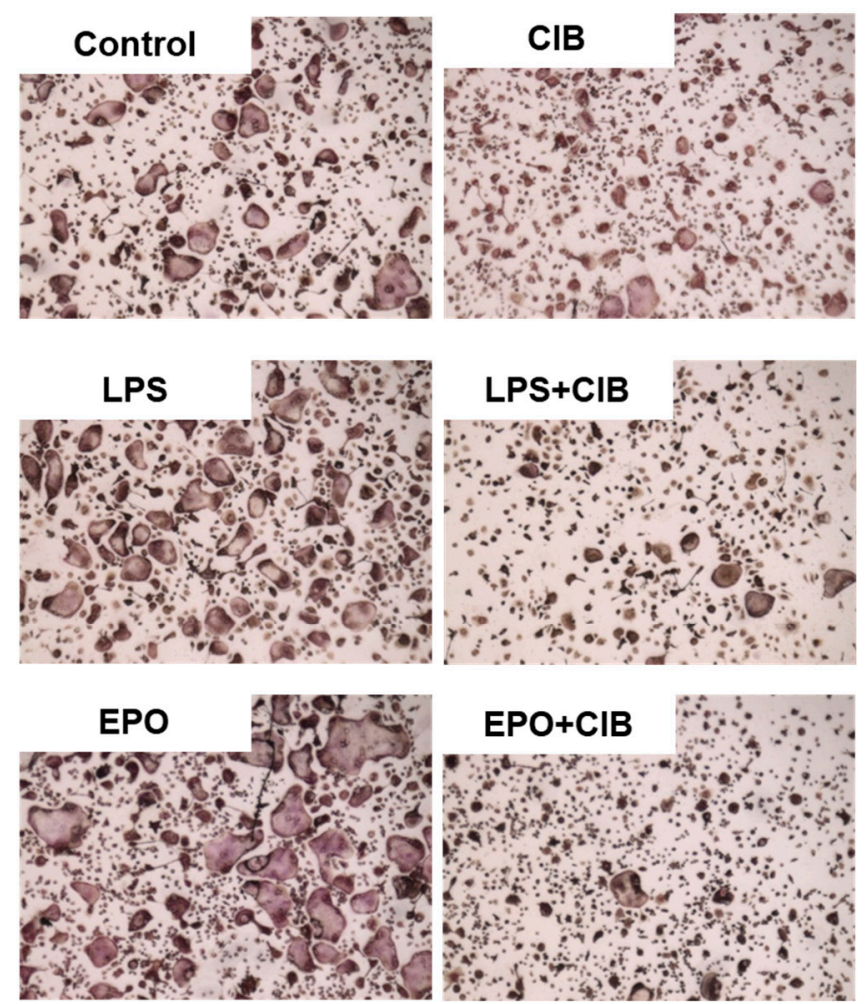

b.

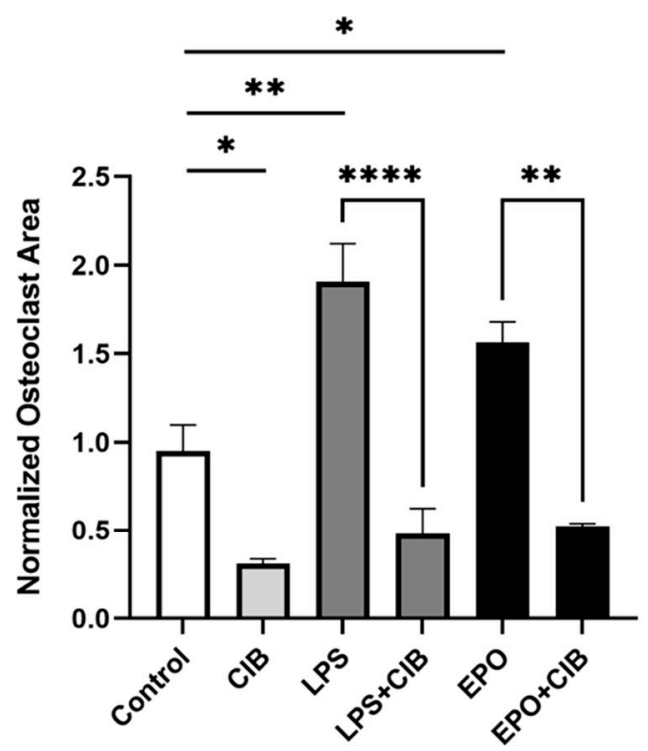

Figure 4. Cibinetide (CIB) counteracts the effect of EPO on preosteoclasts in vitro. BMDMs were treated with RANKL (50 ng/mL) along with EPO $(10 \mathrm{U} / \mathrm{mL})$, Cibinetide $(150 \mu \mathrm{M})$, or EPO + Cibinetide. On the second day, LPS $(10 \mathrm{ng} / \mathrm{mL})$ was introduced to the RANKL or to the RANKL + Cibinetide cultures. On the fourth day, the multinucleated osteoclasts were stained for TRAP. (a) Representative micrographs of $\mathrm{TRAP}^{+}$osteoclasts. Original magnification at $2 \times$. (b) Quantification of the total area of TRAP ${ }^{+}$ multinucleated cells that were normalized to the values of the control group (RANKL). The data are mean \pm SEM of three independent experiments. ${ }^{*} p<0.05,{ }^{* *} p<0.01,{ }^{* * * *} p<0.0001$.

\subsection{Cibinetide (CIB) Increases Tissue Mineral Density (TMD) in Both Cortical and Trabecular Bone}

To investigate the effect of Cibinetide on bone density, we injected 12-week-old female C57BL/6J mice with Cibinetide $(120 \mu \mathrm{g} / \mathrm{kg} \times 3 /$ week for 4 weeks $)$. At the end of the fourth week, hemoglobin levels were measured and the femurs were analyzed by $\mu \mathrm{CT}$. As expected, Cibinetide treatment did not have any effect on hemoglobin levels (Figure 5a). However, it did cause a $5.8 \%$ increase in the cortical TMD and a $5.2 \%$ increase in the trabecular TMD, while the trabecular bone fraction (BV/TV) was unchanged (Figure 5b,c). To gain more insight into the effect of Cibinetide on bone, we analyzed the expression level of OPG and RANKL in the whole bones of Cibinetide-treated and untreated mice. In line with the observed increase in TMD, Cibinetide treatment resulted in a significant $52.4 \%$ increase in the expression of OPG in the whole bone, with no change in the expression of RANKL (Figure 5d).

\subsection{Cibinetide (CIB) Modulates Alkaline Phosphatase (ALP) and CD115 Expression on CD11b- Bone Marrow Cells}

As the next stage, we assessed the effect of Cibinetide on the percentage of preosteoblasts $\left(\mathrm{CD} 11 \mathrm{~b}^{-} \mathrm{ALP}^{+}\right)$as well as preosteoclasts $\left(\mathrm{CD} 11 \mathrm{~b}^{-} \mathrm{CD} 115^{+}\right)$in the bone marrow [47]. The results (Figure 6a), indicate that Cibinetide treatment did not affect the percentage of these two cell populations in the bone marrow. Importantly, Cibinetide treatment resulted in a $25.59 \%$ increase in ALP expression and a $17.79 \%$ decrease in CD115 
expression on the surface of the CD11b- bone marrow cells (Figure $6 \mathrm{~b}, \mathrm{c}$ ). These results further support a Cibinetide-mediated increase in osteoblast mineralizing activity and a decrease in the potential for osteoclast differentiation and are in accordance with our findings that are presented in Figure 5.

a. Hemoglobin

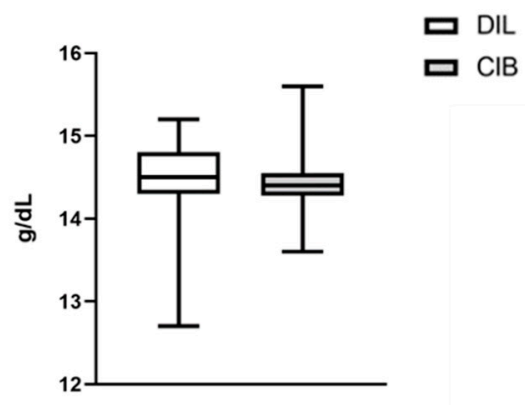

b.

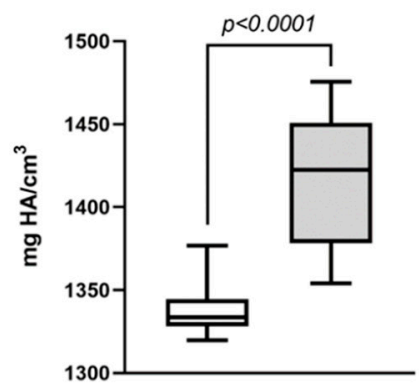

c.

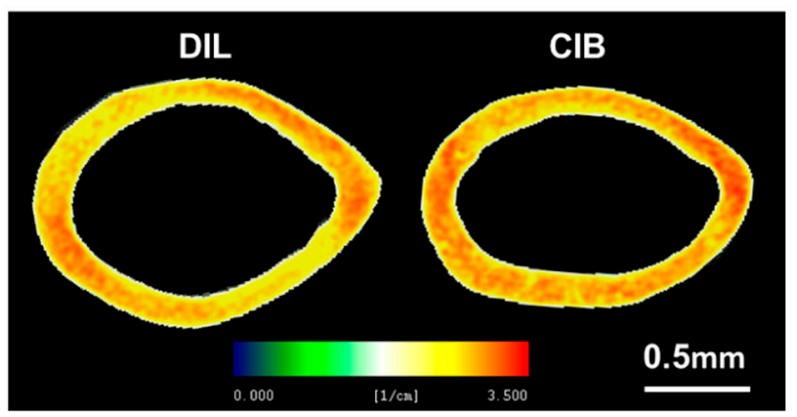

Trab. TMD

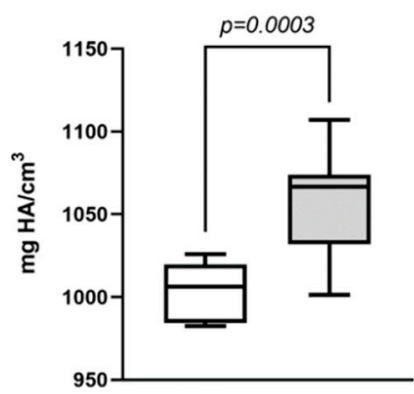

BV/TV

口 DIL

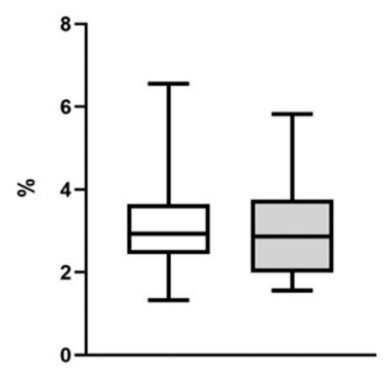

d. Bone Tissue

ㅁ DIL

口 CIB

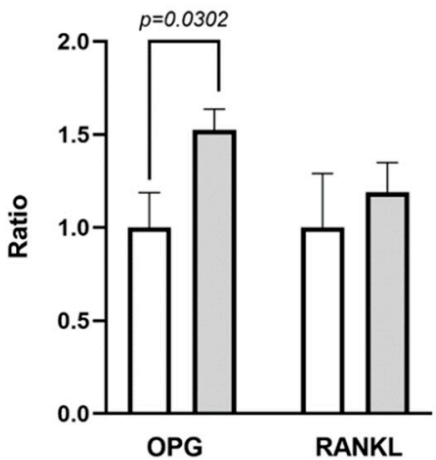

Figure 5. Cibinetide (CIB) increases tissue mineral density (TMD) in both cortical and trabecular bone. (a) Hemoglobin levels in Cibinetide versus diluent injected mice. (b) $\mu \mathrm{CT}$ analysis in the middiaphyseal cortical and distal trabecular femoral bone of diluent and Cibinetide injected 12-week-old female mice with respective representative images (c). Box plots represent median, quartiles and extremes. In (c), the color spectrum reflects the mineral density gradient across the section of the cortical bone. The upper limit of the scale $(3.5 / \mathrm{cm})$ corresponds to $1764 \mathrm{mg} \mathrm{HA} / \mathrm{cm}^{3}$. (d) OPG and RANKL mRNA expression levels in whole bone from diluent vs. Cibinetide treated mice. In (d) ${ }^{\Delta \Delta} \mathrm{CT}$ values are normalized to the diluent group; values are mean \pm SEM. $N=9-10$ mice in each group. 
a.

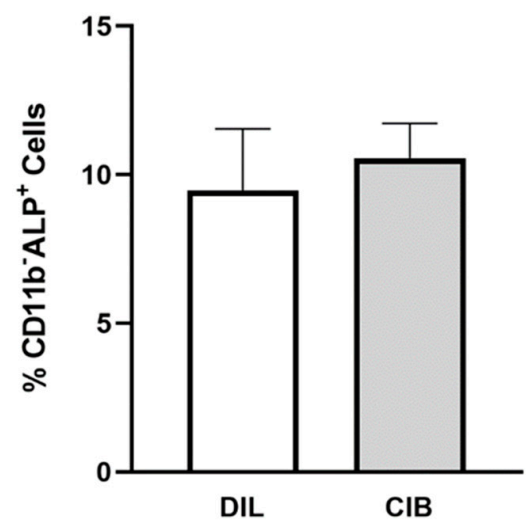

b.

\section{Gated on CD11b- Cells}

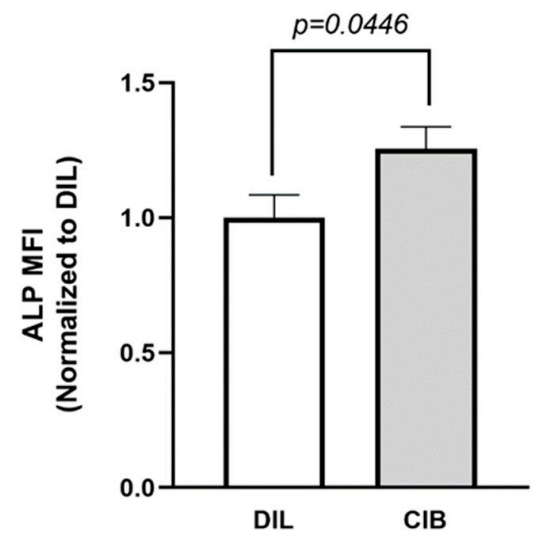

c.

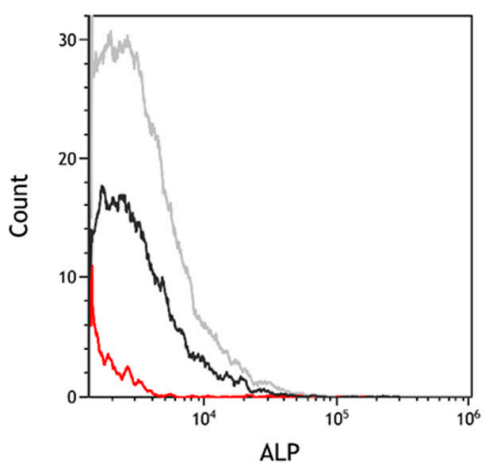

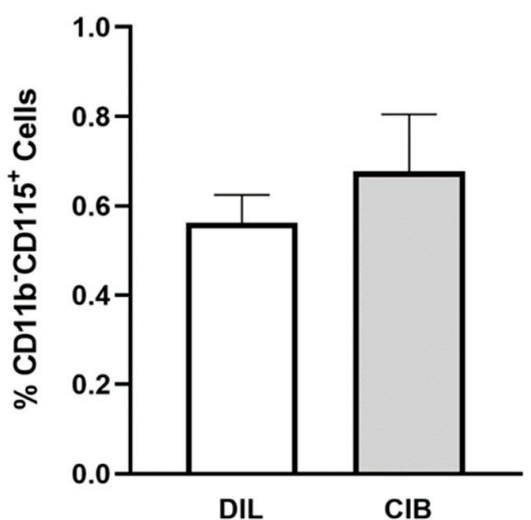
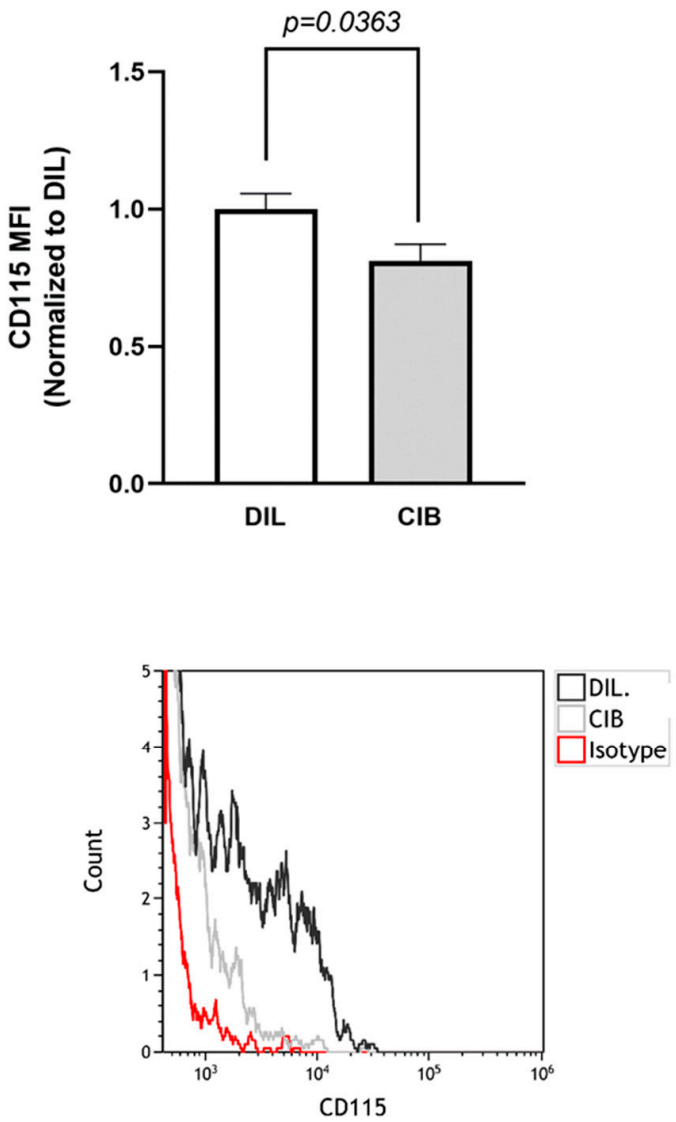

Figure 6. In vivo effects of Cibinetide (CIB) on bone cell precursors. Flow cytometry analysis of osteoblast $\left(\mathrm{CD}_{11} \mathrm{~b}^{-} \mathrm{ALP}^{+}\right)$and osteoclast precursors $\left(\mathrm{CD} 11 \mathrm{~b}^{-} \mathrm{CD} 115^{+}\right)$of total bone marrow from diluent and Cibinetide injected mice. (a) Percentage of cells in the bone marrow. (b) Surface expression (mean fluorescence intensity (MFI)) of ALP and CD115 on CD11b ${ }^{-}$cells in Cibinetide vs. diluent treated mice. (c) Representative overlay histograms of ALP and CD115 expression on CD11b ${ }^{-}$cells. The data are mean \pm SEM. $N=9-10$ mice in each group.

\subsection{Cibinetide (CIB) Overrides the Pro-Osteoclastogenic Effects of EPO In Vivo}

To evaluate the capacity of Cibinetide to counteract the effect of EPO on osteoclasts in vivo, we performed a short-term experiment in which 13-week-old female mice were administered Cibinetide $(300 \mu \mathrm{g} / \mathrm{kg})$ for 5 consecutive days, with 2 injections of $120 \mathrm{U}$ EPO 
on days 1 and 4 . These mice were compared to mice that were receiving either Cibinetide or EPO and also to untreated control mice.

Flow cytometry analysis revealed an $81.06 \%$ increase in the number of osteoclast progenitors, defined as $\mathrm{Lin}^{-} \mathrm{CD} 11 \mathrm{~b}^{-} \mathrm{Ly} 6 \mathrm{C}^{\text {hi }} \mathrm{CD} 115^{+}$[48-51], in the EPO injected mice. However, this was reduced by $42.8 \%$ in the EPO + Cibinetide-injected mice compared to the EPO-injected mice, without any change in the numbers of osteoblast precursors (Figure 7a). Moreover, Cibinetide treatment downregulated CD115 expression on the osteoclast precursors both when given alone and in combination with EPO, while EPO had no effect (Figure $7 \mathrm{~b}$ ). As the next step, we performed an ex vivo osteoclastogenesis assay where a fixed number of BM cells that were collected from mice in each treatment group were cultured in the presence of M-CSF + RANKL. The number of osteoclasts that were measured in this assay reflects the proportion of osteoclast progenitors in the mice at the end of the treatment. The results indicated that cultures that were derived from the EPO-treated mice exhibited a higher degree of osteoclastogenesis than the control cultures, although the difference did not reach statistical significance. Of note, a single injection of EPO at a higher dose (180 U) resulted in an increase both in the proportion of osteoclast progenitors and in the level of CD115 surface expression, as measured after $48 \mathrm{~h}$ (Supplementary Materials, Figure S1)). Importantly, the level of osteoclastogenesis in cells from the Cibinetide and EPO + Cibinetide-injected mice was significantly lower than that from either the control or EPO groups (Figure 7c).

a.

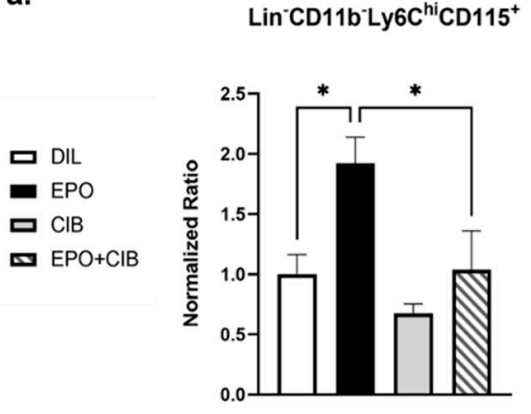

CD11b-ALP $^{+}$

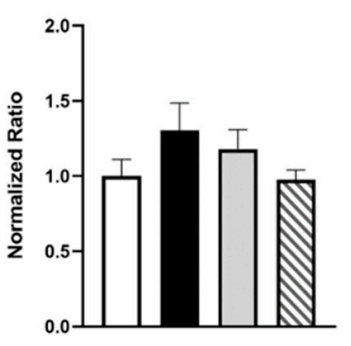

c.

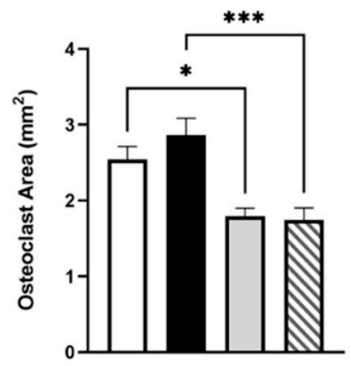

b.

Gated on Lin'CD11b-Ly6C hi Cells

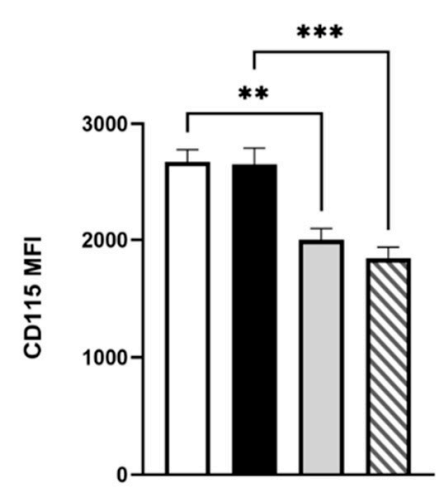

Gated on CD11b- Cells

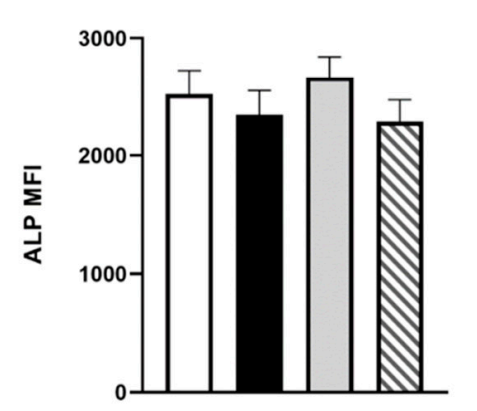

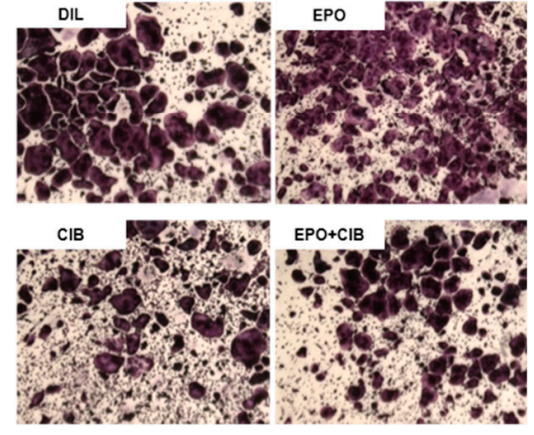

Figure 7. Reduced osteoclast progenitor numbers in combined EPO + Cibinetide (CIB) treatment. (a) Flow cytometry analysis of osteoclast progenitors-containing population $\mathrm{Lin}^{-}\left(\mathrm{CD} 3 \varepsilon^{-}, \mathrm{B}_{2} 20^{-}\right.$,

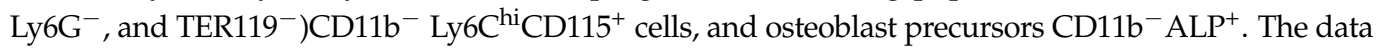
are mean \pm SEM of values that are normalized to the diluent group. (b) Surface expression (mean fluorescence intensity (MFI)) of CD115 and ALP in diluent vs. EPO, Cibinetide or EPO + Cibinetidetreated mice. (c) Total area of multinucleated TRAP ${ }^{+}$osteoclasts grown ex vivo with M-CSF and RANKL from non-adherent bone marrow cells that were isolated from mice treated with either diluent, EPO, Cibinetide, or $\mathrm{EPO}+$ Cibinetide. Right, representative images acquired at $\times 2$ magnification. All data are mean \pm SEM. $N=7$ in each group. ${ }^{*} p<0.05,{ }^{* *} p<0.01,{ }^{* * *} p<0.001$. 
With this short-term treatment, no changes in the bone parameters were detected by $\mu \mathrm{CT}$ in any of the treatment groups (Supplementary Materials, Figure S2).

\subsection{EPO Maintains Erythropoietic Activity in the Presence of Cibinetide (CIB)}

To exclude the possibility that Cibinetide antagonizes the erythropoietic effects of EPO on erythroid cells, we measured hemoglobin levels and spleen weights. In addition, we evaluated the levels of TER $119^{+}$erythroid progenitor cells in the spleen and bone marrow by flow cytometry. As expected, the EPO treatment resulted in a significant increase in all these parameters and none of the erythropoietic changes that were mediated by EPO were affected by Cibinetide (Figure 8).

a.

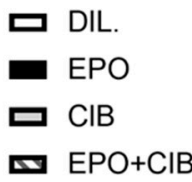

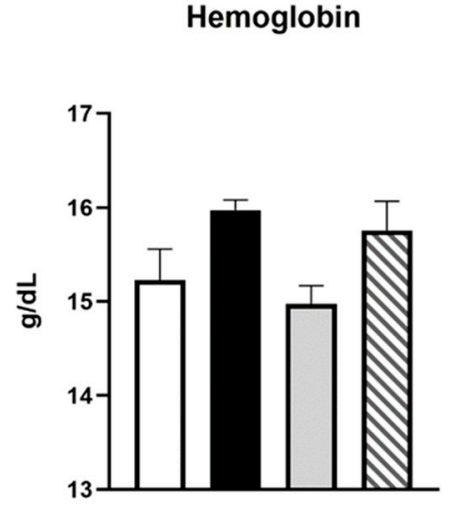

c.

TER119+ Cells in the BM

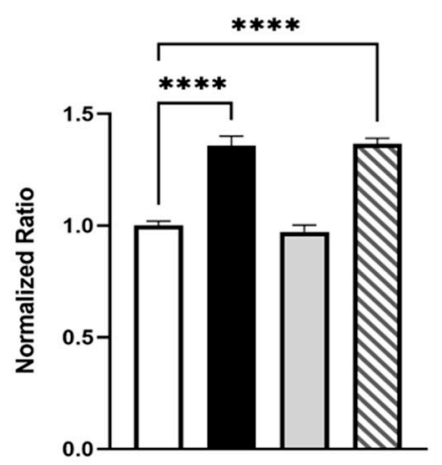

b.

Spleen Weight
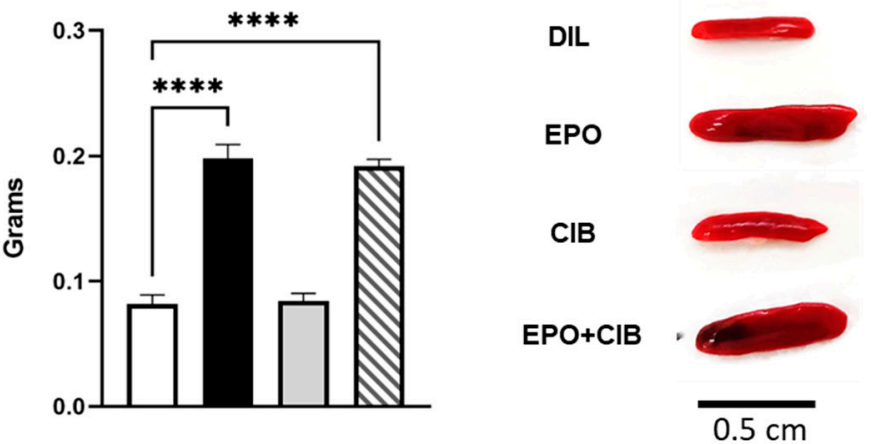

d.

TER119+ Cells in the Spleen

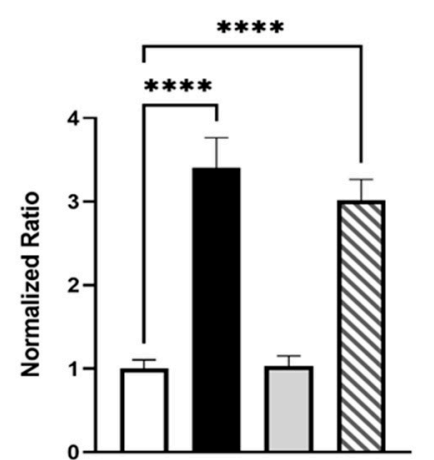

Figure 8. Cibinetide (CIB) does not interfere with the erythropoietic response to Erythropoietin. (a) Hemoglobin levels. (b) Average weights of the spleens with respective representative photographs from untreated, EPO, Cibinetide, EPO + Cibinetide-treated mice. (c,d) Flow cytometry analysis of TER119 ${ }^{+}$erythroid progenitors in the bone marrow (c) and in the spleen (d). Values on the Y axis represent the normalized ratio of the Ter $119^{+}$cells in each treatment group relative to the diluent control. Values are mean \pm SEM. $N=7$ mice in each group. ${ }^{* * *} p<0.0001$.

\section{Discussion}

While the beneficial anti-inflammatory effects of Cibinetide, a selective IRR agonist, have been well-documented in multiple systems for over a decade now [52], there is no record of the effect on the skeletal system, which is one of the most studied targets of EPO.

This study is the first to address the in vitro and in vivo effects of Cibinetide on bone metabolism, either alone or in combination with EPO. 
Our results reveal that Cibinetide can counteract the stimulatory effects of EPO on the monocytic-lineage by decreasing the pool of osteoclast precursors that were defined as

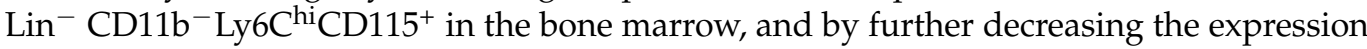
of CD115 in this population. The observation that this is achieved without interference with the erythropoietic activity of EPO, reflects the specificity of the effect on osteoclast progenitors in the bone marrow.

The finding that Cibinetide acts in the early stages of osteoclast differentiation is evidenced by the downregulation of the key transcription factor NFATC1, as well as suppression of the osteoclast differentiation-related genes CTSK, OSCAR, DC-STAMP, and OC-STAMP. Interestingly, EPO has previously been reported by us [38] and others [53,54] to have an osteoclast stimulatory effect.

These seemingly opposing effects of the two EPOR ligands on preosteoclasts in vitro motivated us to examine the interplay between the two ligands during osteoclastogenesis. Importantly, the results revealed that the inhibitory effect of Cibinetide could negate the stimulatory effect that was induced by EPO.

Considering the potent anti-inflammatory activities of Cibinetide in LPS-activated macrophages $[24,55,56]$, and the fact that LPS is a potent inducer of inflammation and inflammatory bone loss [57], our finding that Cibinetide mitigates LPS-induced osteoclastogenesis may have significant clinical applications, for example in inflammation-induced osteolysis (e.g., [58-60]). It should be noted that the components of the heteromeric EPOR and CD131 complex are usually intracellular in the non-inflammatory state and typically are not expressed by healthy tissues although they are rapidly induced under stress conditions [61]. The robust in vitro anti-osteoclastogenic effects of Cibinetide (in the presence of RANKL and M-CSF), prompted us to investigate whether Cibinetide can also confer a bone preserving effect in vivo, in healthy mice.

The administration of Cibinetide to wild-type female mice resulted in a significant increase in TMD, which is an important contributor to bone mineral density (BMD) in cortical and trabecular bone, while the BV/TV remained unchanged after Cibinetide treatment. TMD is a measure of the mineral content inside the trabecular and cortical bone whereas BV/TV measures the amount of trabecular and cortical bone over the total volume of the region of interest. At the resolution that was employed here $(10 \mu \mathrm{m})$, TMD will thus reflect the mineral density as well as the microscopic porosity (pores of $<10-15 \mu \mathrm{m}$ ) as the measured bone volume will include these small voids that cannot be detected due to the resolution. This microscopic porosity includes osteocyte lacunae [62]. In our study, the Cibinetide-induced increase in TMD may result from increased mineralization of the bone tissue and/or narrowing of the osteocyte lacunae. BMD combines both TMD and BV/TV. It should be noted that despite the seemingly low increase in TMD $(\sim 5 \%)$, this is a clinically relevant finding since a $5-10 \%$ decline is associated with approximately $50-100 \%$ higher fracture rates [63].

Interestingly, the Cibinetide results are very different from the effect that was observed after exogenous EPO administration in mice, where a massive decrease in trabecular bone fraction is evident albeit with no effect on TMD (data not shown).

The increased expression levels of OPG in the bone tissue of Cibinetide treated mice, are a possible mechanism for the reduced osteoclastogenesis, reduced bone resorption and increased TMD.

This assumption is further supported by a recent study reporting that EPOR regulates OPG expression in osteo-progenitors and regulates osteoblast function and osteoblastmediated osteoclastogenesis via the RANKL/OPG axis [42]. The question of whether EPO acts on osteoblasts via the EPOR/CD131 heterodimer remains to be addressed.

Despite the similar proportions of preosteoblasts and preosteoclasts in the bone marrow of Cibinetide-injected mice, we found an increased surface expression of alkaline phosphatase, an early osteogenic marker of bone formation and mineralization on preosteoblasts. In addition, there was a decrease in the expression of CD115, one of the receptors for osteoclastogenic factors which acts as a potent stimulator of RANK expression 
on preosteoclasts [64]. In line with these findings, the downregulation, blockade, or depletion of CD115 has been shown to suppress the formation and activity of osteoclasts and to attenuate the pathological bone resorption that is seen in inflammatory bone destruction and osteoporosis [65-68]. Similarly, TLR ligands mediate the downregulation of CD115 from the cell surface and suppress osteoclastogenesis [69].

Taken together, our data provide evidence that Cibinetide acts on preosteoblasts to increase bone formation and also reduces bone resorption capacity by suppressing the differentiation of preosteoclasts to osteoclasts.

Another cytokine receptor that shares the $\beta$ chain (CD131) of the heteromeric complex is IL-3. In one study, IL-3 was shown to decrease the expression of CD115 glycoprotein and mRNA in a murine myeloid precursor cell line [70] and in another study, it was found to inhibit human osteoclastogenesis and bone resorption through downregulation of CD115 and diverting the cells to the dendritic cell lineage [71]. These findings raise certain questions regarding the role of the CD131 subunit in bone remodeling.

In this context, it is interesting that CD131 knockout mice exhibit normal development, although they develop pulmonary peribronchovascular lymphoid infiltrates and areas resembling alveolar proteinosis [72], and the numbers of eosinophils are reduced in the peripheral blood and bone marrow. Notably, the tissue-protective properties of EPO do not function in these animals although they display normal hematopoiesis [13,55]. In another study, the very challenging conditional deletion of CD131 in a specific subpopulation through the myeloid lineage CCR2 ${ }^{+} \mathrm{Ly} 6 \mathrm{C}^{\text {hi }}$ was achieved and used to study experimental autoimmune encephalomyelitis (EAE) [73].

In the future, we predict that a similar approach of generating osteoclast-specific and osteoblast-specific conditional CD131 knockout may strengthen our conclusion that the heteromer EPOR/CD131 mediates the effects of EPO and Cibinetide in these bone cells.

The current study used only a short-term treatment of the combination of Cibinetide and EPO. Our choice of a five-day treatment regimen was based on our findings of a very early and rapid increase in osteoclast progenitors two days after a single EPO injection (2.25-fold increase vs. untreated). With our short duration of treatment, we could not detect any changes in bone microarchitecture in any of the treated groups, but we did observe significant differences in the osteoclast lineage, in line with the skeletal effects of CIB that were observed (Figure 5).

The findings that are reported here add more complexity to the notion that the two ligands induce similar tissue protective activities and differ only in their erythropoietic capacity. To our knowledge, this is the first scenario in which Cibinetide and EPO have opposing effects. Whether this is due to different pharmacokinetics or to diverging signaling pathways remains to be elucidated.

In this context, it should be noted that although Cibinetide has a short plasma half-life ( $2 \mathrm{~min})$ [74], it has sustained biological effects [52], even when injected with EPO, which is a molecule with a long half-life (4-6 h) [52].

In light of the fact that all of the currently used anti-resorptive drugs for the treatment of osteoporosis have adverse side effects, an intense focus has been directed toward developing new therapeutic agents that can inhibit bone resorption and enhance bone formation [75].

Our data introduce Cibinetide as an appealing candidate for the treatment of bone loss either as a stand-alone therapy for osteolytic pathologies ranging from cancer to rheumatoid arthritis and osteoporosis, or in combination with EPO for patients with anemia or cancer. The results that are presented here suggest that treatment with Cibinetide and EPO may prevent or attenuate bone loss while preserving the erythropoietic actions of EPO.

\section{Materials and Methods}

\subsection{Materials}

Alpha-MEM and fetal bovine serum (FBS), were purchased from Rhenium (Modiin, Israel) and culture plates were from Corning (New York, NY, USA). LPS from the E. coli 
strain 0127:B8 (Sigma) was reconstituted in sterile double distilled water (DDW) as a $1 \mathrm{mg} / \mathrm{mL}$ stock solution and kept at $-20^{\circ} \mathrm{C}$. Dulbecco's Phosphate Buffered Saline (DPBS) was purchased from Biological Industries. As a source of M-CSF, we used supernatant from CMG 14-12 cells containing $1.3 \mu \mathrm{g} / \mathrm{mL}$ M-CSF [38,76]. RANKL was purchased from R\&D Systems, Minneapolis, MN, USA. The peptide Cibinetide was kindly provided by Araim Pharmaceuticals, Inc. (Ossining, NY, USA). Erythropoietin (EPO) was obtained from GMP-manufactured sterile syringes containing rHuEPO (Epoetin alfa, Eprex ${ }^{\circledR}$ ) as used for patient care. These were kindly provided by Janssen Cilag, Israel, and were employed throughout this study.

\subsection{Animals}

Female wild-type mice of the inbred strain C57BL/6J-RccHsd, aged 8-13 weeks, were purchased from Envigo (Jerusalem, Israel) and housed at the Tel-Aviv University animal facility. Animal care and all procedures were in accordance with, and with the approval of, the Tel Aviv University Institutional Animal Care and Use Committee (Permit number 01-19-032).

\subsection{Cell Culture}

In vitro osteoclastogenesis: Bone marrow cells were harvested from the femurs and tibias of 8- to 13-week-old female mice. The cells were seeded on tissue-culture treated plates in standard medium ( $\alpha$-MEM supplemented with $10 \%$ fetal bovine serum). On the following day, the non-adherent cells were seeded in non-tissue culture-treated plates in standard medium supplemented with $100 \mathrm{ng} / \mathrm{mL}$ M-CSF [77], which induces cell proliferation and differentiation into preosteoclasts.

For the osteoclastogenesis assay, preosteoclasts were plated in 96 -well plates (8000 cells per well) with standard medium that was supplemented with $20 \mathrm{ng} / \mathrm{mL}$ M-CSF and $50 \mathrm{ng} / \mathrm{mL}$ RANKL (R\&D Systems), which was replaced every 2 days. Treatments in culture (EPO, Cibinetide, LPS) were added together with RANKL, as indicated. On the 4-5th day, the multinucleated osteoclasts [78] were stained using a tartrate-resistant acid phosphatase (TRAP) [79] kit (Sigma-Aldrich, St Louis, MO, USA) and the relative TRAP-positive surface was measured using ImageJ software.

Ex vivo osteoclastogenesis: The bone marrow cells were harvested from the femurs and tibias of 13-week-old female mice and were then seeded into tissue culture-treated plates in standard medium and allowed to attach overnight. Non-adherent cells were plated into 96 well plates in standard medium that was supplemented with M-CSF (in the form of $2 \% v / v$ culture supernatant from CMG 14-12 cells), and $50 \mathrm{ng} / \mathrm{mL}$ recombinant murine RANKL. The medium was replaced every other day. After 6-7 days, the cells were stained for tartrate-resistant acid phosphatase (TRAP) and the relative TRAP-positive surface was measured using ImageJ software.

\subsection{Microcomputed Tomography (microCT)}

The femurs (one per mouse) were examined using the $\mu$ CT50 system (Scanco Medical AG, Wangen-Brüttisellen, Switzerland) [80,81]. Briefly, scans were performed at a $10 \mu \mathrm{m}$ resolution, $90 \mathrm{kV}$ energy, $114 \mathrm{~mA}$ intensity, and $1100 \mathrm{msec}$ integration time. The mineralized tissues were segmented by a global thresholding procedure following Gaussian filtration of the stacked tomographic images [82]. Trabecular bone parameters were measured in the secondary spongiosa of the distal femoral metaphysis. Cortical parameters were determined in a $1 \mathrm{~mm}$ height ring in the mid-diaphyseal region.

\subsection{Hemoglobin Levels}

Hemoglobin $(\mathrm{Hgb})$ levels were measured in venous blood (that was drawn from the facial vein) by means of a "Mission Plus" hemoglobin/hematocrit meter (Acon, San Diego, CA, USA). 


\subsection{MTT (3-(4,5-Dimethylthiazol-2-yl)-2,5-Diphenyltetrazolium Bromide) Assay}

Cell viability was determined using an MTT assay, essentially as described previously [83]. The bone marrow-derived macrophages (BMDM) were seeded into 96-well plates $\left(1 \times 10^{4}\right.$ cells/well) and then incubated with $100 \mathrm{ng} / \mathrm{mL}$ M-CSF in the presence of various concentrations of Cibinetide. After $48 \mathrm{~h}$ of incubation, MTT $(0.5 \mathrm{mg} / \mathrm{mL})$ was added to each well for $3 \mathrm{~h}$. At the end of the incubation, the insoluble formazan products were dissolved in acidic isopropanol, and absorbance at $560 \mathrm{~nm}$ was measured to assess the number of viable cells (proliferation and cytotoxicity).

\subsection{Flow Cytometry}

The bone marrow (BM) cells were flushed from the femurs or tibias, and the red blood cells were lysed using ACK lysis buffer (Quality Biological, Gaithersburg, MD). The cells were then stained for $20 \mathrm{~min}$ at $4{ }^{\circ} \mathrm{C}$ with conjugated anti-mouse antibodies (see Table 1 for a list of the antibodies that were used). After this time, cells were washed with PBS containing 1\% FBS and analyzed by either Gallios or Cytoflex flow cytometers and Kaluza or CytExpert software (all from Beckman Coulter, Indianapolis, Indiana 46268, USA).

Table 1. Antibodies used for flow cytometry analysis.

\begin{tabular}{ccc}
\hline Antibody & Source & Identifier \\
\hline TER-119-APC & BioLegend & Cat\#: 116211 \\
CD71-PE & BioLegend & Cat\#: 113807 \\
CD11b-APC & BioLegend & Cat\#:101211 \\
CD115-PE & Miltenyi Biotec & Cat\#: 130112828 \\
LY6G-FITC & BioLegend & Cat\#: 127605 \\
TER119-FITC & BioLegend & Cat\#: 116205 \\
CD3e-FITC & BioLegend & Cat\#: 100305 \\
B220-FITC & BioLegend & Cat\#:103205 \\
LY6C- PerCP/Cy5.5 & BioLegend & Cat\#: 128011 \\
Alkaline Phosphatase (ALPL) & R\&D systems & Cat\#: AF2910 \\
CD115-APC & eBioscience & Cat\#: 14115282 \\
Goat IgG (H+L)-PE & R\&D systems & Cat\#: F0107 \\
\hline
\end{tabular}

\subsection{Real-Time RT PCR}

Total RNA was extracted from BMDM using the TriRNA Pure kit (Cat\#TRPD200, Geneaid, New Taipei City, Taiwan) and cDNA was synthesized using the qScript cDNA synthesis kit (Quantabio, MA, USA). "Real-time" quantitative PCR (RQ-PCR) was performed on a StepOnePlus instrument using the SYBR Green reagent (both from Applied Biosystems, CA, USA). The relative gene expression was calculated using the $\Delta \triangle \mathrm{CT}$ method following normalization to the expression of HPRT as a housekeeping gene.

The primers that were used for PCR were as follows: (F, forward; $R$, reverse):

DC-STAMP, F TCCTCCATGAACAAACAGTTCCAA; DC-STAMP, R AGACGTGGTTTAGGAATGCAGCTC; OC-STAMP, F TTGCTCCTGTCCTACAGTGC; OC-STAMP, R GCCCTCAGTAACACAGCTCA; NFATC1, F GAGTACACCTTCCAGCACCTT; NFATC1, R TATGATGTCGGGAAAGAGA; HPRT, F TCCTCCTCAGACCGCTTTT; HPRT, R CCTGGTTCATCATCGCTAATC; OSCAR, F CGTGCTGACTTCACACCAAC; OSCAR, R GGTCACGTTGATCCCAGGAG; Cathepsin K, F GATACTGGACACCCACTGGGA; Cathepsin K, R CATTCTCAGACACAATCCAC; RANKL, F CATTCTCAGACACAATCCAC; RANKL, R ACATCCAACCATGAGCCTTC; OPG, F GAGACACAGCTCACAAGAGCAA; OPG, R GCTTTCACAGAGGTCAATGTCTT.

\subsection{Statistical Analysis}

The values are expressed as mean \pm SEM (standard error of the mean). A Student's $t$-test was used for calculating the statistical significance when comparing two groups of variables. In experiments with $>2$ groups of variables, a one-way ANOVA was applied. The 
level of statistical significance was set at $p \leq 0.05$. Asterisks between bars indicate significant differences between two groups $\left({ }^{*} p \leq 0.05,{ }^{* *} p \leq 0.01,{ }^{* * *} p \leq 0.001\right.$, and $\left.{ }^{* * * *} p \leq 0.0001\right)$. All statistical analyses were performed using Prism 9 (GraphPad).

Supplementary Materials: The following are available online at https://www.mdpi.com/article/10 $.3390 /$ ijms23010055/s1.

Author Contributions: Conceptualization, Z.A., D.N., and Y.G.; methodology, Z.A., A.B., H.S., A.G., N.B.-C., M.I., A.K., J.A.I., L.G.V., T.L., and S.H.-B.; formal analysis, Z.A., A.B., H.S., and N.B.C. resources, M.B.; data curation, Z.A.; writing-original draft preparation, Z.A., D.N., and Y.G.; writing-review and editing, Z.A., D.N., and Y.G.; visualization, Z.A., D.N., and Y.G.; supervision, D.N. and Y.G.; funding acquisition, D.N. and Y.G. All authors have read and agreed to the published version of the manuscript.

Funding: This research was funded by Israel Science Foundation (ISF) grants number 1086/17 to YG and number 1188/21 to DN and by a grant from the Dotan Hemato-oncology Fund, the Cancer Biology Research Center, Tel Aviv University to DN and YG. DN holds The Lily and Avraham Gildor Chair for the Investigation of Growth Factors.

Institutional Review Board Statement: Animal care and all procedures were in accordance with, and with the approval of, the Tel Aviv University Institutional Animal Care and Use Committee (Permit number 01-19-032).

Informed Consent Statement: Not applicable.

Acknowledgments: This work was carried out in partial fulfillment of the requirements for a Ph.D. degree for Z.A. from the Sackler Faculty of Medicine, Tel Aviv University, Tel Aviv, Israel.

Conflicts of Interest: The authors declare no conflict of interest.

\section{References}

1. Wu, H.; Liu, X.; Jaenisch, R.; Lodish, H.F. Generation of committed erythroid BFU-E and CFU-E progenitors does not require erythropoietin or the erythropoietin receptor. Cell 1995, 83, 59-67. [CrossRef]

2. Sasaki, R.; Masuda, S.; Nagao, M. Erythropoietin: Multiple physiological functions and regulation of biosynthesis. Biosci. Biotechnol. Biochem. 2000, 64, 1775-1793. [CrossRef] [PubMed]

3. Spivak, J.L.; Pham, T.; Isaacs, M.; Hankins, W.D. Erythropoietin is both a mitogen and a survival factor. Blood 1991, 77, 1228-1233. [CrossRef]

4. Ramanath, V.; Gupta, D.; Jain, J.; Chaudhary, K.; Nistala, R. Anemia and chronic kidney disease: Making sense of the recent trials. Rev. Recent Clin. Trials 2012, 7, 187-196. [CrossRef]

5. Wish, J.B. Past, present, and future of chronic kidney disease anemia management in the United States. Adv. Chronic Kidney Dis. 2009, 16, 101-108. [CrossRef] [PubMed]

6. Ohashi, Y.; Uemura, Y.; Fujisaka, Y.; Sugiyama, T.; Ohmatsu, H.; Katsumata, N.; Okamoto, R.; Saijo, N.; Hotta, T. Meta-analysis of epoetin beta and darbepoetin alfa treatment for chemotherapy-induced anemia and mortality: Individual patient data from Japanese randomized, placebo-controlled trials. Cancer Sci. 2013, 104, 481-485. [CrossRef]

7. Westenbrink, B.D.; Lipsic, E.; van der Meer, P.; van der Harst, P.; Oeseburg, H.; Du Marchie Sarvaas, G.J.; Koster, J.; Voors, A.A.; van Veldhuisen, D.J.; van Gilst, W.H.; et al. Erythropoietin improves cardiac function through endothelial progenitor cell and vascular endothelial growth factor mediated neovascularization. Eur. Heart J. 2007, 28, 2018-2027. [CrossRef]

8. Van der Meer, P.; Lipsic, E. Erythropoietin: Repair of the failing heart. J. Am. Coll. Cardiol. 2006, 48, 185-186. [CrossRef]

9. Pankratova, S.; Kiryushko, D.; Sonn, K.; Soroka, V.; Kohler, L.B.; Rathje, M.; Gu, B.; Gotfryd, K.; Clausen, O.; Zharkovsky, A.; et al. Neuroprotective properties of a novel, non-haematopoietic agonist of the erythropoietin receptor. Brain 2010, 133, $2281-2294$. [CrossRef] [PubMed]

10. Nakano, M.; Satoh, K.; Fukumoto, Y.; Ito, Y.; Kagaya, Y.; Ishii, N.; Sugamura, K.; Shimokawa, H. Important role of erythropoietin receptor to promote VEGF expression and angiogenesis in peripheral ischemia in mice. Circ. Res. 2007, 100, 662-669. [CrossRef]

11. Tsai, P.T.; Ohab, J.J.; Kertesz, N.; Groszer, M.; Matter, C.; Gao, J.; Liu, X.; Wu, H.; Carmichael, S.T. A critical role of erythropoietin receptor in neurogenesis and post-stroke recovery. J. Neurosci. 2006, 26, 1269-1274. [CrossRef]

12. Lifshitz, L.; Tabak, G.; Gassmann, M.; Mittelman, M.; Neumann, D. Macrophages as novel target cells for erythropoietin. Haematologica 2010, 95, 1823-1831. [CrossRef]

13. Brines, M.; Grasso, G.; Fiordaliso, F.; Sfacteria, A.; Ghezzi, P.; Fratelli, M.; Latini, R.; Xie, Q.W.; Smart, J.; Su-Rick, C.J.; et al. Erythropoietin mediates tissue protection through an erythropoietin and common beta-subunit heteroreceptor. Proc. Natl. Acad. Sci. USA 2004, 101, 14907-14912. [CrossRef]

14. Brines, M.; Cerami, A. The receptor that tames the innate immune response. Mol. Med. 2012, 18, 486-496. [CrossRef] 
15. Blake, T.J.; Jenkins, B.J.; D'Andrea, R.J.; Gonda, T.J. Functional cross-talk between cytokine receptors revealed by activating mutations in the extracellular domain of the beta-subunit of the GM-CSF receptor. J. Leukoc. Biol. 2002, 72, $1246-1255$.

16. Jubinsky, P.T.; Krijanovski, O.I.; Nathan, D.G.; Tavernier, J.; Sieff, C.A. The beta chain of the interleukin-3 receptor functionally associates with the erythropoietin receptor. Blood 1997, 90, 1867-1873. [CrossRef] [PubMed]

17. Hercus, T.R.; Dhagat, U.; Kan, W.L.; Broughton, S.E.; Nero, T.L.; Perugini, M.; Sandow, J.J.; D'Andrea, R.J.; Ekert, P.G.; Hughes, T.; et al. Signalling by the betac family of cytokines. Cytokine Growth Factor Rev. 2013, 24, 189-201. [CrossRef]

18. Leist, M.; Ghezzi, P.; Grasso, G.; Bianchi, R.; Villa, P.; Fratelli, M.; Savino, C.; Bianchi, M.; Nielsen, J.; Gerwien, J.; et al. Derivatives of erythropoietin that are tissue protective but not erythropoietic. Science 2004, 305, 239-242. [CrossRef] [PubMed]

19. Brines, M.; Patel, N.S.; Villa, P.; Brines, C.; Mennini, T.; De Paola, M.; Erbayraktar, Z.; Erbayraktar, S.; Sepodes, B.; Thiemermann, C.; et al. Nonerythropoietic, tissue-protective peptides derived from the tertiary structure of erythropoietin. Proc. Natl. Acad. Sci. USA 2008, 105, 10925-10930. [CrossRef] [PubMed]

20. Liu, Y.; Luo, B.; Han, F.; Li, X.; Xiong, J.; Jiang, M.; Yang, X.; Wu, Y.; Zhang, Z. Erythropoietin-derived nonerythropoietic peptide ameliorates experimental autoimmune neuritis by inflammation suppression and tissue protection. PLoS ONE 2014, 9, e90942. [CrossRef]

21. Pulman, K.G.; Smith, M.; Mengozzi, M.; Ghezzi, P.; Dilley, A. The erythropoietin-derived peptide ARA290 reverses mechanical allodynia in the neuritis model. Neuroscience 2013, 233, 174-183. [CrossRef]

22. Dahan, A.; Dunne, A.; Swartjes, M.; Proto, P.L.; Heij, L.; Vogels, O.; van Velzen, M.; Sarton, E.; Niesters, M.; Tannemaat, M.R.; et al. ARA 290 improves symptoms in patients with sarcoidosis-associated small nerve fiber loss and increases corneal nerve fiber density. Mol. Med. 2013, 19, 334-345. [CrossRef] [PubMed]

23. Brines, M.; Dunne, A.N.; van Velzen, M.; Proto, P.L.; Ostenson, C.G.; Kirk, R.I.; Petropoulos, I.N.; Javed, S.; Malik, R.A.; Cerami, A.; et al. ARA 290, a nonerythropoietic peptide engineered from erythropoietin, improves metabolic control and neuropathic symptoms in patients with type 2 diabetes. Mol. Med. 2015, 20, 658-666. [CrossRef]

24. Huang, B.; Jiang, J.; Luo, B.; Zhu, W.; Liu, Y.; Wang, Z.; Zhang, Z. Non-erythropoietic erythropoietin-derived peptide protects mice from systemic lupus erythematosus. J. Cell. Mol. Med. 2018, 22, 3330-3339. [CrossRef]

25. Yao, M.; Watanabe, M.; Sun, S.; Tokodai, K.; Cerami, A.; Brines, M.; Ostenson, C.G.; Ericzon, B.G.; Lundgren, T.; Kumagai-Braesch, M. Improvement of islet allograft function using cibinetide, an innate repair receptor ligand. Transplantation 2020, 104, 2048-2058. [CrossRef] [PubMed]

26. Clarke, B. Normal bone anatomy and physiology. Clin. J. Am. Soc. Nephrol. 2008, 3, S131-S139. [CrossRef]

27. Karsenty, G.; Kronenberg, H.M.; Settembre, C. Genetic control of bone formation. Annu. Rev. Cell. Dev. Biol. 2009, 25, 629-648. [CrossRef] [PubMed]

28. Teitelbaum, S.L. Osteoclasts: What do they do and how do they do it? Am. J. Pathol. 2007, 170, 427-435. [CrossRef]

29. Zaidi, M. Skeletal remodeling in health and disease. Nat. Med. 2007, 13, 791-801. [CrossRef] [PubMed]

30. Teitelbaum, S.L.; Ross, F.P. Genetic regulation of osteoclast development and function. Nat. Rev. Genet. 2003, 4, 638-649. [CrossRef]

31. Boyle, W.J.; Simonet, W.S.; Lacey, D.L. Osteoclast differentiation and activation. Nature 2003, 423, 337-342. [CrossRef]

32. Takayanagi, H. Osteoimmunology: Shared mechanisms and crosstalk between the immune and bone systems. Nat. Rev. Immunol. 2007, 7, 292-304. [CrossRef] [PubMed]

33. Lappin, K.M.; Mills, K.I.; Lappin, T.R. Erythropoietin in bone homeostasis-Implications for efficacious anemia therapy. Stem Cells Transl. Med. 2021, 10, 836-843. [CrossRef] [PubMed]

34. Hiram-Bab, S.; Neumann, D.; Gabet, Y. Erythropoietin in bone-Controversies and consensus. Cytokine 2017, 89, 155-159. [CrossRef]

35. Hiram-Bab, S.; Neumann, D.; Gabet, Y. Context-dependent skeletal effects of erythropoietin. Vitam. Horm. 2017, 105, 161-179.

36. Bulycheva, E.; Rauner, M.; Medyouf, H.; Theurl, I.; Bornhauser, M.; Hofbauer, L.C.; Platzbecker, U. Myelodysplasia is in the niche: Novel concepts and emerging therapies. Leukemia 2015, 29, 259-268. [CrossRef] [PubMed]

37. Singbrant, S.; Russell, M.R.; Jovic, T.; Liddicoat, B.; Izon, D.J.; Purton, L.E.; Sims, N.A.; Martin, T.J.; Sankaran, V.G.; Walkley, C.R. Erythropoietin couples erythropoiesis, B-lymphopoiesis, and bone homeostasis within the bone marrow microenvironment. Blood 2011, 117, 5631-5642. [CrossRef] [PubMed]

38. Hiram-Bab, S.; Liron, T.; Deshet-Unger, N.; Mittelman, M.; Gassmann, M.; Rauner, M.; Franke, K.; Wielockx, B.; Neumann, D.; Gabet, Y. Erythropoietin directly stimulates osteoclast precursors and induces bone loss. FASEB J. 2015, 29, 1890-1900. [CrossRef] [PubMed]

39. Suresh, S.; de Castro, L.F.; Dey, S.; Robey, P.G.; Noguchi, C.T. Erythropoietin modulates bone marrow stromal cell differentiation. Bone Res. 2019, 7, 21. [CrossRef]

40. Suresh, S.; Alvarez, J.C.; Dey, S.; Noguchi, C.T. Erythropoietin-induced changes in bone and bone marrow in mouse models of diet-induced obesity. Int. J. Mol. Sci. 2020, 21, 1657. [CrossRef] [PubMed]

41. Kolomansky, A.; Hiram-Bab, S.; Ben-Califa, N.; Liron, T.; Deshet-Unger, N.; Mittelman, M.; Oster, H.S.; Rauner, M.; Wielockx, B.; Neumann, D.; et al. Erythropoietin mediated bone loss in mice is dose-dependent and mostly irreversible. Int. J. Mol. Sci. 2020, 21, 3817. [CrossRef] [PubMed]

42. Rauner, M.; Murray, M.; Thiele, S.; Watts, D.; Neumann, D.; Gabet, Y.; Hofbauer, L.C.; Wielockx, B. Epo/EpoR signaling in osteoprogenitor cells is essential for bone homeostasis and Epo-induced bone loss. Bone Res. 2021, 9, 42. [CrossRef] 
43. Kristjansdottir, H.L.; Lewerin, C.; Lerner, U.H.; Herlitz, H.; Johansson, P.; Johansson, H.; Karlsson, M.; Lorentzon, M.; Ohlsson, C.; Ljunggren, O.; et al. High plasma erythropoietin predicts incident fractures in elderly men with normal renal function: The MrOS Sweden cohort. J. Bone Miner. Res. 2020, 35, 298-305. [CrossRef] [PubMed]

44. Suresh, S.; Wright, E.C.; Wright, D.G.; Abbott, K.C.; Noguchi, C.T. Erythropoietin treatment and the risk of hip fractures in hemodialysis patients. J. Bone Miner. Res. 2021, 36, 1211-1219. [CrossRef]

45. Teitelbaum, S.L. Bone resorption by osteoclasts. Science 2000, 289, 1504-1508. [CrossRef]

46. Pereira, M.; Petretto, E.; Gordon, S.; Bassett, J.H.D.; Williams, G.R.; Behmoaras, J. Common signalling pathways in macrophage and osteoclast multinucleation. J. Cell Sci. 2018, 131, jcs216267. [CrossRef]

47. Pippenger, B.E.; Duhr, R.; Muraro, M.G.; Pagenstert, G.I.; Hugle, T.; Geurts, J. Multicolor flow cytometry-based cellular phenotyping identifies osteoprogenitors and inflammatory cells in the osteoarthritic subchondral bone marrow compartment. Osteoarthr. Cartil. 2015, 23, 1865-1869. [CrossRef]

48. Das, A.; Wang, X.; Kang, J.; Coulter, A.; Shetty, A.C.; Bachu, M.; Brooks, S.R.; Dell'Orso, S.; Foster, B.L.; Fan, X.; et al. Monocyte subsets with high osteoclastogenic potential and their epigenetic regulation orchestrated by IRF8. J. Bone Miner. Res. 2021, 36, 199-214. [CrossRef] [PubMed]

49. Charles, J.F.; Hsu, L.Y.; Niemi, E.C.; Weiss, A.; Aliprantis, A.O.; Nakamura, M.C. Inflammatory arthritis increases mouse osteoclast precursors with myeloid suppressor function. J. Clin. Investig. 2012, 122, 4592-4605. [CrossRef]

50. Park-Min, K.H.; Lee, E.Y.; Moskowitz, N.K.; Lim, E.; Lee, S.K.; Lorenzo, J.A.; Huang, C.; Melnick, A.M.; Purdue, P.E.; Goldring, S.R.; et al. Negative regulation of osteoclast precursor differentiation by CD11b and beta2 integrin-B-cell lymphoma 6 signaling. J. Bone Miner. Res. 2013, 28, 135-149. [CrossRef]

51. Omar, I.; Guterman-Ram, G.; Rahat, D.; Tabach, Y.; Berger, M.; Levaot, N. Schlafen2 mutation in mice causes an osteopetrotic phenotype due to a decrease in the number of osteoclast progenitors. Sci. Rep. 2018, 8, 13005. [CrossRef]

52. Collino, M.; Thiemermann, C.; Cerami, A.; Brines, M. Flipping the molecular switch for innate protection and repair of tissues: Long-lasting effects of a non-erythropoietic small peptide engineered from erythropoietin. Pharmacol. Ther. 2015, 151, 32-40. [CrossRef] [PubMed]

53. Shiozawa, Y.; Jung, Y.; Ziegler, A.M.; Pedersen, E.A.; Wang, J.; Wang, Z.; Song, J.; Lee, C.H.; Sud, S.; Pienta, K.J.; et al. Erythropoietin couples hematopoiesis with bone formation. PLoS ONE 2010, 5, e10853. [CrossRef] [PubMed]

54. Sadvakassova, G.; Tiedemann, K.; Steer, K.J.D.; Mikolajewicz, N.; Stavnichuk, M.; In-Kyung Lee, I.; Sabirova, Z.; Schranzhofer, M.; Komarova, S.V. Active hematopoiesis triggers exosomal release of PRDX2 that promotes osteoclast formation. Physiol. Rep. 2021, 9, e14745. [CrossRef] [PubMed]

55. Nairz, M.; Haschka, D.; Dichtl, S.; Sonnweber, T.; Schroll, A.; Asshoff, M.; Mindur, J.E.; Moser, P.L.; Wolf, D.; Swirski, F.K.; et al. Cibinetide dampens innate immune cell functions thus ameliorating the course of experimental colitis. Sci. Rep. 2017, 7, 13012. [CrossRef]

56. Watanabe, M.; Lundgren, T.; Saito, Y.; Cerami, A.; Brines, M.; Ostenson, C.G.; Kumagai-Braesch, M. A nonhematopoietic erythropoietin analogue, ARA 290, inhibits macrophage activation and prevents damage to transplanted islets. Transplantation 2016, 100, 554-562. [CrossRef]

57. Inada, M.; Matsumoto, C.; Uematsu, S.; Akira, S.; Miyaura, C. Membrane-bound prostaglandin E synthase-1-mediated prostaglandin E2 production by osteoblast plays a critical role in lipopolysaccharide-induced bone loss associated with inflammation. J. Immunol. 2006, 177, 1879-1885. [CrossRef]

58. Eger, M.; Sterer, N.; Liron, T.; Kohavi, D.; Gabet, Y. Scaling of titanium implants entrains inflammation-induced osteolysis. Sci. Rep. 2017, 7, 39612. [CrossRef]

59. Eger, M.; Hiram-Bab, S.; Liron, T.; Sterer, N.; Carmi, Y.; Kohavi, D.; Gabet, Y. Mechanism and prevention of titanium particleinduced inflammation and osteolysis. Front. Immunol. 2018, 9, 2963. [CrossRef]

60. Eger, M.; Liron, T.; Hiram-Bab, S.; Awida, Z.; Giladi, E.; Dangoor, D.; Fridkin, M.; Kohavi, D.; Gozes, I.; Gabet, Y. Therapeutic potential of vasoactive intestinal peptide and its derivative stearyl-norleucine-vip in inflammation-induced osteolysis. Front. Pharmacol. 2021, 12, 638128. [CrossRef]

61. Peng, B.; Kong, G.; Yang, C.; Ming, Y. Erythropoietin and its derivatives: From tissue protection to immune regulation. Cell Death Dis. 2020, 11, 79. [CrossRef] [PubMed]

62. Palacio-Mancheno, P.E.; Larriera, A.I.; Doty, S.B.; Cardoso, L.; Fritton, S.P. 3D assessment of cortical bone porosity and tissue mineral density using high-resolution microCT: Effects of resolution and threshold method. J. Bone Miner. Res. 2014, 29, 142-150. [CrossRef]

63. Finkelstein, J.S.; Brockwell, S.E.; Mehta, V.; Greendale, G.A.; Sowers, M.R.; Ettinger, B.; Lo, J.C.; Johnston, J.M.; Cauley, J.A.; Danielson, M.E.; et al. Bone mineral density changes during the menopause transition in a multiethnic cohort of women. J. Clin. Endocrinol. Metab. 2008, 93, 861-868. [CrossRef] [PubMed]

64. Arai, F.; Miyamoto, T.; Ohneda, O.; Inada, T.; Sudo, T.; Brasel, K.; Miyata, T.; Anderson, D.M.; Suda, T. Commitment and differentiation of osteoclast precursor cells by the sequential expression of $\mathrm{c}$-Fms and receptor activator of nuclear factor kappaB (RANK) receptors. J. Exp. Med. 1999, 190, 1741-1754. [CrossRef] [PubMed]

65. Paniagua, R.T.; Chang, A.; Mariano, M.M.; Stein, E.A.; Wang, Q.; Lindstrom, T.M.; Sharpe, O.; Roscow, C.; Ho, P.P.; Lee, D.M.; et al. C-Fms-mediated differentiation and priming of monocyte lineage cells play a central role in autoimmune arthritis. Arthritis Res. Ther. 2010, 12, R32. [CrossRef] 
66. Wang, X.F.; Wang, Y.J.; Li, T.Y.; Guo, J.X.; Lv, F.; Li, C.L.; Ge, X.T. Colony-stimulating factor 1 receptor inhibition prevents against lipopolysaccharide -induced osteoporosis by inhibiting osteoclast formation. Biomed. Pharmacother. 2019, 115, 108916. [CrossRef]

67. Zhu, M.; Sun, B.H.; Nevius, E.; Kaplan, J.; Pereira, J.; Insogna, K. Selective deletion of the receptor for CSF1, c-fms, in osteoclasts results in a high bone mass phenotype, smaller osteoclasts in vivo and an impaired response to an anabolic PTH regimen. PLoS ONE 2021, 16, e0247199. [CrossRef]

68. Lee, K.; Kim, M.Y.; Ahn, H.; Kim, H.S.; Shin, H.I.; Jeong, D. Blocking of the ubiquitin-proteasome system prevents inflammationinduced bone loss by accelerating M-CSF receptor c-Fms degradation in osteoclast differentiation. Int. J. Mol. Sci. 2017, 18, 2054 [CrossRef]

69. Ji, J.D.; Park-Min, K.H.; Shen, Z.; Fajardo, R.J.; Goldring, S.R.; McHugh, K.P.; Ivashkiv, L.B. Inhibition of RANK expression and osteoclastogenesis by TLRs and IFN-gamma in human osteoclast precursors. J. Immunol. 2009, 183, 7223-7233. [CrossRef] [PubMed]

70. Gliniak, B.C.; Rohrschneider, L.R. Expression of the M-CSF receptor is controlled posttranscriptionally by the dominant actions of GM-CSF or multi-CSF. Cell 1990, 63, 1073-1083. [CrossRef]

71. Gupta, N.; Barhanpurkar, A.P.; Tomar, G.B.; Srivastava, R.K.; Kour, S.; Pote, S.T.; Mishra, G.C.; Wani, M.R. IL-3 inhibits human osteoclastogenesis and bone resorption through downregulation of c-Fms and diverts the cells to dendritic cell lineage. J. Immunol. 2010, 185, 2261-2272. [CrossRef]

72. Robb, L.; Drinkwater, C.C.; Metcalf, D.; Li, R.; Kontgen, F.; Nicola, N.A.; Begley, C.G. Hematopoietic and lung abnormalities in mice with a null mutation of the common beta subunit of the receptors for granulocyte-macrophage colony-stimulating factor and interleukins 3 and 5. Proc. Natl. Acad. Sci. USA 1995, 92, 9565-9569. [CrossRef] [PubMed]

73. Croxford, A.L.; Lanzinger, M.; Hartmann, F.J.; Schreiner, B.; Mair, F.; Pelczar, P.; Clausen, B.E.; Jung, S.; Greter, M.; Becher, B The cytokine GM-CSF drives the inflammatory signature of CCR2+ monocytes and licenses autoimmunity. Immunity 2015, 43, 502-514. [CrossRef]

74. Van Velzen, M.; Heij, L.; Niesters, M.; Cerami, A.; Dunne, A.; Dahan, A.; Brines, M. ARA 290 for treatment of small fiber neuropathy in sarcoidosis. Expert Opin. Investig. Drugs 2014, 23, 541-550. [CrossRef] [PubMed]

75. Teitelbaum, S.L. Therapeutic implications of suppressing osteoclast formation versus function. Rheumatology 2016, 55, ii61-ii63. [CrossRef]

76. Takeshita, S.; Kaji, K.; Kudo, A. Identification and characterization of the new osteoclast progenitor with macrophage phenotypes being able to differentiate into mature osteoclasts. J. Bone Miner. Res. 2000, 15, 1477-1488. [CrossRef] [PubMed]

77. Marino, S.; Logan, J.G.; Mellis, D.; Capulli, M. Generation and culture of osteoclasts. Bonekey Rep. 2014, 3, 570. [CrossRef]

78. Hata, K.; Kukita, T.; Akamine, A.; Kukita, A.; Kurisu, K. Trypsinized osteoclast-like multinucleated cells formed in rat bone marrow cultures efficiently form resorption lacunae on dentine. Bone 1992, 13, 139-146. [CrossRef]

79. Minkin, C. Bone acid phosphatase: Tartrate-resistant acid phosphatase as a marker of osteoclast function. Calcif. Tissue Int. 1982, 34, 285-290. [CrossRef] [PubMed]

80. Noh, T.; Gabet, Y.; Cogan, J.; Shi, Y.; Tank, A.; Sasaki, T.; Criswell, B.; Dixon, A.; Lee, C.; Tam, J.; et al. Lef1 haploinsufficient mice display a low turnover and low bone mass phenotype in a gender- and age-specific manner. PLoS ONE 2009, 4, e5438. [CrossRef]

81. Gabet, Y.; Baniwal, S.K.; Leclerc, N.; Shi, Y.; Kohn-Gabet, A.E.; Cogan, J.; Dixon, A.; Bachar, M.; Guo, L.; Turman, J.E., Jr.; et al Krox20/EGR2 deficiency accelerates cell growth and differentiation in the monocytic lineage and decreases bone mass. Blood 2010, 116, 3964-3971. [CrossRef] [PubMed]

82. Ruegsegger, P.; Koller, B.; Muller, R. A microtomographic system for the nondestructive evaluation of bone architecture Calcif. Tissue Int. 1996, 58, 24-29. [CrossRef] [PubMed]

83. Mosmann, T. Rapid colorimetric assay for cellular growth and survival: Application to proliferation and cytotoxicity assays. J. Immunol. Methods 1983, 65, 55-63. [CrossRef] 